\title{
Amazonian Bacuri (Platonia insignis Mart.) Fruit Waste Valorisation Using Response Surface Methodology
}

\author{
Klenicy K. L. Yamaguchi ${ }^{1, *}$, David S. Dias ${ }^{2}$, Carlos Victor Lamarão ${ }^{3}$, Karen F. A. Castelo ${ }^{4}$, Max S. Lima ${ }^{4}$, \\ Ananda S. Antonio ${ }^{5}\left(\mathbb{D}\right.$, Attilio Converti ${ }^{6}\left(\mathbb{D}\right.$, Emerson S. Lima ${ }^{7, *(1)}$ and Valdir F. Veiga-Junior $8, *(\mathbb{D})$
}

1 Institute of Health and Biotechnology, Federal University of Amazonas, Coari 69460-000, Brazil

2 Institute of Mathematical and Computer Sciences, University of São Paulo, São Carlos 13566-590, Brazil; souzaddias@gmail.com

3 Agricultural Products Technology Laboratory, Faculty of Agricultural Science, Federal University of Amazonas, Manaus 69080-900, Brazil; victorlamarao@yahoo.com.br

4 Chemistry Department, Institute of Exact Sciences, Federal University of Amazonas, Manaus 69077-000, Brazil; karen.falves@gmail.com (K.F.A.C.); maxlima@ufam.edu.br (M.S.L.)

5 Center for Forensic Analysis, Laboratory for the Support of Technological Development, Chemistry Institute, Federal University of Rio de Janeiro (NAF-LADETEC/IQ-UFRJ), Rio de Janeiro 21941-598, Brazil; ananda.antonio@gmail.com

6 Department of Civil, Chemical and Environmental Engineering, Pole of Chemical Engineering, University of Genoa, I-16145 Genoa, Italy; converti@unige.it

7 Faculty of Pharmaceutical Sciences, Federal University of Amazonas, Manaus 69080-900, Brazil

8 Chemical Engineering Section, Military Institute of Engineering, Rio de Janeiro 22290-270, Brazil

* Correspondence: klenicy@ufam.edu.br (K.K.L.Y.); eslima@ufam.edu.br (E.S.L.); valdir.veiga@gmail.com (V.F.V.-J.)

Citation: Yamaguchi, K.K.L.; Dias, D.S.; Lamarão, C.V.; Castelo, K.F.A.; Lima, M.S.; Antonio, A.S.; Converti, A.; Lima, E.S.; Veiga-Junior, V.F. Amazonian Bacuri (Platonia insignis Mart.) Fruit Waste Valorisation Using Response Surface Methodology. Biomolecules 2021, 11, 1767. https:// doi.org/10.3390/biom11121767

Academic Editor: Vito Verardo

Received: 27 October 2021

Accepted: 22 November 2021

Published: 25 November 2021

Publisher's Note: MDPI stays neutral with regard to jurisdictional claims in published maps and institutional affiliations.

Copyright: () 2021 by the authors. Licensee MDPI, Basel, Switzerland. This article is an open access article distributed under the terms and conditions of the Creative Commons Attribution (CC BY) license (https:// creativecommons.org/licenses/by/ $4.0 /)$.
Abstract: Bacuri (Platonia insignis Mart) is a species from the Clusiaceae genus. Its fruit pulp is commonly used in South America in several food products, such as beverages, ice cream and candies. Only the pulp of the fruit is used, and the peels and seeds are considered waste from these industries. As a trioxygenated xanthone source, this species is of high interest for bioproduct development. This work evaluated the mesocarp and epicarp of bacuri fruits through different extraction methods and experimental conditions ( $\mathrm{pH}$, temperature and solvent) in order to determine the most effective method for converting this agro-industrial waste in a value-added bioproduct. Open-column procedures and HPLC and NMR experiments were performed to evaluate the chemical composition of the extracts, along with total phenols, total flavonoids and antioxidant activities (sequestration of the DPPH and ABTS radicals). A factorial design and response surface methodology were used. The best extraction conditions of substances with antioxidant properties were maceration at $50{ }^{\circ} \mathrm{C}$ with $100 \%$ ethanol as solvent for mesocarp extracts, and acidic sonication in $100 \%$ ethanol for epicarp extracts, with an excellent phenolic profile and antioxidant capacities. The main compounds isolated were the prenylated benzophenones garcinielliptone FC (epicarp) and 30-epi-cambogin (mesocarp). This is the first study analysing the performance of extraction methods within bacuri agro-industrial waste. Results demonstrated that shells and seeds of bacuri can be used as phenolicrich bioproducts obtained by a simple extraction method, increasing the value chain of this fruit.

Keywords: bacuri; Amazonia; Platonia insignis; antioxidants; prenylated benzophenones; food residues; biorefinery; response surface methodology; radical scavenging capacity; green chemistry

\section{Introduction}

Bacuri is a South American species of Clusiaceae named Platonia insignis Mart. It is found from Paraguay to Suriname and is widely distributed in the Amazon and Cerrado biomes [1]. The fruit is famous for its pleasant and bittersweet taste, being largely consumed in food products such as beverages, ice cream and candies, for its sensorial attributes and for 
its remarkable biological properties [2,3]. Despite its commercial potential, its production still relies on extractivism, with an annual production of 3,061 tonnes of fresh fruit in 2017 [4,5]. The pulp used in the production of food comprises only $26 \%$ of the fresh fruit's weight, with the other $58 \%$ of the weight considered waste [5-7]. This significant waste of biomass could be used to improve the local bioeconomy and develop new bioproducts, as several studies reported that $P$. insignis's volatile fractions and the polar extracts of its seeds are rich in antioxidant, anti-inflammatory, anticonvulsant, antiparasitic, hypotensive and immunoregulatory compounds [1-3,8]. Moreover, the chemical profile of the bioproduct highlights terpenes and phenolic compounds as its main bioactive compounds $[9,10]$.

Phenolic compounds are of great interest to industry due to their antioxidant potential. The food and cosmetics industries, in particular, have been using them as food preservatives and active agents for antiaging skin creams, respectively. In addition, they are also used in so-called healthy foods as well as the treatment of diseases resulting from the action of free radicals $[3,11]$. Fruit peels and seeds, which are generally not used in industrial processes, may be promising sources of phenolic substances. However, there are still few initiatives to develop processes so that industries can use this waste. For instance, none of the published research of $P$. insignis has aimed to determine better processing methods to add value to its agro-industrial waste. The studies on Amazonian biodiversity still rely mainly on chemical characterization [12,13], searching for patterns [14] or drug development based on traditional knowledge [15].

The optimization of extraction processes of biologically active substances is a procedure that has become considerably more common in recent years [16-18], and the search for sustainable, efficient and selective extraction methods is one of the main goals of industry. Generally, the effectiveness of the extraction of phenolic compounds from natural products is influenced by multiple factors, such as extraction temperature, time, water-toraw-material ratio, pressure, and type of solvent. In related studies, results are commonly processed with the aid of statistical tools, such as response surface methodology [19-22], which allow for the selection of optimal conditions under which it is possible to recover the maximum number of compounds of interest. There are few reports on the optimization of the extraction of crude phenolic compounds from $P$. insignis and their antioxidant activities $[8,10,11]$. Therefore, due the growing consumption of this fruit, its described biological properties and the number of bioactive substances in its extract, here it is proposed to determine the best extraction method for antioxidant substances from bacuri shell (mesocarp and epicarp) using the response surface methodology in order to obtain a valuable bioproduct.

\section{Materials and Methods}

\subsection{Chemicals and Reagents}

Trolox (6-hydroxy-2,5,7,8-tetramethylchroman-2-caboxylic acid) (Sigma-Aldrich, St. Louis, MO, USA), DPPH (2,2-diphenyl-picrylhydrazyl) (Sigma-Aldrich, St. Louis, MO, USA), gallic acid (Sigma-Aldrich, St. Louis, MO, USA), quercetin (Sigma-Aldrich, St. Louis, MO, USA), DMSO (Sigma-Aldrich, St. Louis, MO, USA), TMS (Sigma-Aldrich, St. Louis, $\mathrm{MO}, \mathrm{USA}$ ), $\mathrm{CH}_{3} \mathrm{OD}$ (Sigma-Aldrich, St. Louis, MO, USA), and CDCl3 (Sigma-Aldrich, St. Louis, MO, USA), and Folin-Ciocalteu reagent (Sigma-Aldrich Chemie, Steinheim, Germany) was used. Ethanol (Merck, Darmstadt, Germany) and methanol (Merck, Darmstadt, Germany), the extraction solvents, were HPLC grade.

\subsection{Biological Samples}

Shells from P. insignis were provided by the Fazenda Bacuri, located in Bragança city, Pará state, Brazil. A voucher sample was deposited at UFAM herbarium and the biological sampling was registered on the National System of Genetic Resource Management and Associated Traditional Knowledge (SISGEN), in accordance with Brazilian legislation regarding biodiversity scientific exploitation. Shells were manually removed from ripe 
fruits and divided in mesocarp (PM) and epicarp (PE). Both shell parts were dried in an air circulation oven at $40^{\circ} \mathrm{C}$ for $48 \mathrm{~h}$, before being crushed in a knife mill.

\subsection{Extraction Procedures and Analysis}

Evaluation of the extraction technique and solvent was done through a set of experiments carried out according to a $2^{4}$-factorial experimental design. The levels used for the extraction technique were cold maceration (CM), hot maceration (HM), neutral sonication (NS), and acid sonication (AS). CM and HM required the sample to be submersed in the extraction solvent for $24 \mathrm{~h}$ at room temperature $\left(25.0 \pm 0.5^{\circ} \mathrm{C}\right)$ and for $2 \mathrm{~h}$ at $50{ }^{\circ} \mathrm{C}$, respectively. Both NS and AS were ultrasound-assisted extractions performed in a bath-type ultrasound apparatus (Q1.8/40A model, $40 \mathrm{kHz}$ frequency, Ultronique, Brazil) for $20 \mathrm{~min}$ at room temperature $\left(25 \pm 0.5^{\circ} \mathrm{C}\right)$, with the only difference being the addition of $50 \mu \mathrm{L}$ of hydrochloric acid in the extraction solvent used in the latter method. Recent optimization studies regarding phenolic extraction from botanic matrices indicated that acidity solvents can increase extraction performance, depending on the phenolic compounds profile (e.g., flavonoids, anthocyanins, and others) [23-25]. In all extraction methods, a sample-tosolvent ratio of 1:10 $(\mathrm{g} / \mathrm{mL})$ was used. The extraction solvent levels tested were different concentrations of ethanol in the aqueous solvent, namely $100 \%, 80 \%, 50 \%$ and $20 \%$. After each experiment, the obtained extract was dried using a rotary vacuum evaporator (801 model, Fisatom, Brazil) and a desiccator. The dried extracts were stored under refrigeration prior to analysis. The response variables $\left(Y_{i j k}\right)$ used were yield of extraction (\%), total phenolic content $(\%)$, total flavonoid content $(\%)$, antioxidant capacity of the $2,2^{\prime}$-azino-bis (3-ethylbenzothiazoline-6-sulfonic acid) (ABTS) assay expressed as scavenging effect (\%) and antioxidant capacity of the $\mathrm{DPPH}^{\bullet}$ assay expressed as half maximal inhibitory concentration $\left(\mathrm{IC}_{50}, \%\right)$. The structural model used for the factorial design is represented by Equation (1): DPPH

$$
Y_{i j k}=\mu+\tau_{j}+\beta_{k}+\gamma_{j k}+\epsilon_{i j k}
$$

where $\mu=(\mu R, \mu F e, \mu F l)$ is the global mean vector, $\tau_{j}=\left(\tau_{j} R, \tau_{j} F e, \tau_{j} F l\right)$ is the effect of the extraction method $(j), \beta_{k}=\left(\beta_{k} R, \beta_{k} F e, \beta_{k} F l\right)$ is the effect of the type of solvent $(k), \gamma_{j k}=\left(\gamma_{j k} R\right.$, $\left.\gamma_{j k} F e, \gamma_{j k} F l\right)$ is the effect of interaction between extraction method and type of solvent and $\mathrm{E}_{i j k}$ is the random error.

Analysis of the phenolic compound extraction was performed by applying multivariate analysis of variance (MANOVA) to the results of the experimental designs [26]. Statistical analysis was performed using the R. 2.14.0 statistical software (Free Software Foundation, Boston, MA, USA). The response surface methodology was used to identify the best conditions to obtain the active extracts, while the comparison of means and the factor levels (method, and solvent-solvent method) as independent variables was performed by analysis of variance (ANOVA) followed by a Tukey test.

The crude extraction yield was determined using the gravimetric method, taking into account the dry weight of the extract and the weight of botanical material used during extraction. The ethanolic extracts were fractionated with less polar solvents by liquidliquid extraction, followed by open-column chromatography. Identification procedures were performed by mass spectrometry (LCQ Fleet, from Thermo Scientific, operating with APCI and ESI modes, samples inserted directly, in HPLC methanol) and nuclear magnetic resonance (Advance III HD 11.75 Tesla, from Bruker, using TMS as internal standard and $\mathrm{CD}_{3} \mathrm{OD}$ and $\mathrm{CDCl}_{3}$ as solvents).

\subsection{Response Variable Determination}

The extraction methods and optimization of the extraction solvent were performed by the evaluation of five response variables: the crude extraction yield, total phenolic content, total flavonoid content, and the antioxidant activity capacity based on DPPH and ABTS assay. 


\subsubsection{Total Phenolic Content}

The quantification of phenolic compounds was performed according to the FolinCiocalteu method described by Singleton and Rossi [27]. The extracts $(10 \mu \mathrm{L})$ were mixed with $50 \mu \mathrm{L}$ of Folin-Ciocalteu reagent for $8 \mathrm{~min}$, and then $240 \mu \mathrm{L}$ of sodium carbonate were added. After incubation at room temperature for $3 \mathrm{~min}$, the absorbance of the reaction mixture was measured at $715 \mathrm{~nm}$ against a methanol blank using a microplate reader (DTX 800 multimode detector, UV/Vis spectrophotometer, Beckman Coulter, Brea, CA, USA). Gallic acid was used as a standard. The experiments were performed in triplicate. Data of the total phenolic content in the dry matter were expressed as mean percentages.

\subsubsection{Total Flavonoids}

The quantification of total flavonoids was performed by the colorimetric method by Chang et al. [28], adapted to microplate. The extract solution (30 $\mu \mathrm{g}$ of 1:10 g.mL $\mathrm{m}^{-1}$ solution) in dimethyl sulfoxide (DMSO) was individually mixed with $90 \mu \mathrm{L}$ of ethanol, $6 \mu \mathrm{L}$ of $10 \%$ aluminium chloride, $6 \mu \mathrm{L}$ of $1.0 \mathrm{M}$ potassium acetate and $168 \mu \mathrm{L}$ of distilled water. The resulting mixture was maintained at room temperature for $30 \mathrm{~min}$, and its absorbance measured at $405 \mathrm{~nm}$ with the microplate reader described above. All samples were analysed in triplicates. Data of the total flavonoid content in the dry matter were expressed as mean percentages.

\subsubsection{ABTS Radical Scavenging Assay}

ABTS radical cation $\left(\mathrm{ABTS}^{\bullet+}\right)$ scavenging activity was measured by the method reported by Re et al. with minor modification [29]. The ABTS ${ }^{\bullet+}$ solution was prepared by combining the reaction of the ABTS stock solution with $2.45 \mathrm{mM}$ potassium persulfate and allowing the mixture to stand in the dark at room temperature for $12-16 \mathrm{~h}$ before use. The $\mathrm{ABTS}^{\bullet+}$ solution was diluted to the absorbance of $0.70 \pm 0.02$ and stored for offline and online assays. For analysis, $30 \mu \mathrm{L}$ of diluted extracts at different concentrations (1-100 $\mu \mathrm{g} \mathrm{mL}^{-1}$ ) were added to $270 \mu \mathrm{L}$ of $\mathrm{ABTS}^{\bullet+}$ solution and left in the dark at room temperature for $15 \mathrm{~min}$. The absorbance was measured at $630 \mathrm{~nm}$ with the above microplate reader. All determinations were carried out in triplicate for each concentration of either standard or samples. The percentage inhibition of absorbance at $630 \mathrm{~nm}$ was calculated and plotted as a function of concentration of antioxidants and Trolox (standard reference) using Equation (2).

$$
\text { Scavenging effect }(\%)=\left[\frac{\left(A b s_{\text {control }}-A b s_{\text {sample }}\right)}{A b s_{\text {control }}}\right] \times 100
$$

where $A b s_{\text {control }}$ is the absorbance of the control solution without sample.

\subsubsection{DPPH Radical Scavenging Assay}

$\mathrm{DPPH}^{\bullet}$ radical scavenging activity was determined according to the method described by Molyneux with slight modification [30]. A total of $30 \mu \mathrm{L}$ of extracts were diluted in DMSO and mixed with $270 \mu \mathrm{L}$ of DPPH in ethanol on a 96-well plate. After keeping the plate in the dark for $30 \mathrm{~min}$, the absorbance of the solution was measured at $517 \mathrm{~nm}$ in the same microplate as above. Blanks (DMSO) and standards (quercetin solutions in DMSO) were analysed simultaneously. Extracts were first tested only at the concentration of $100 \mu \mathrm{g} \mathrm{mL}{ }^{-1}$, and those showing good evidence of antioxidant activity were tested over a concentration range to determine the $\mathrm{IC}_{50}$. The $\mathrm{IC}_{50}$ was calculated using Equation (3):

$$
\mathrm{IC}_{50}(\%)=\left[\frac{\left(A b s_{\text {blank }}-A b s_{\text {sample }}\right)}{A b s_{\text {blank }}}\right] \times 100
$$


where $A b s_{\text {blank }}$ is the absorbance of the control reaction (containing all reagents except the test compound).

\section{Results and Discussion}

The development of extraction procedures with less toxic solvents to the environment is one of the green chemistry postulates. The solvents most used in the extraction of bioactive compounds are methanol, ethanol, acetone, ethyl acetate and water [23,31]. In order to comply with the green chemistry postulates, ethanol/water mixtures were selected as solvents in this study. The results of tests carried out with different extraction methods at different ethanol percentages in water are summarized in Table 1 for both the mesocarp and epicarp of bacuri (P. insignis).

Table 1. Results of extractions carried out with different methods at different ethanol percentages in water on the mesocarp and epicarp of bacuri.

\begin{tabular}{|c|c|c|c|c|c|c|c|}
\hline \multirow[t]{2}{*}{ Sample } & \multirow{2}{*}{$\begin{array}{l}\text { Extraction } \\
\text { Method }\end{array}$} & \multirow{2}{*}{$\begin{array}{c}\% \text { of } \\
\text { Ethanol }\end{array}$} & \multirow{2}{*}{$\begin{array}{c}\text { Crude } \\
\text { Extraction Yield } \\
(\%) \pm \mathrm{SD} \\
\end{array}$} & \multirow{2}{*}{$\begin{array}{l}\text { Total Phenolic } \\
\text { Compounds } \\
\text { (\% } w / w \pm \mathrm{SD})\end{array}$} & \multirow{2}{*}{$\begin{array}{l}\text { Total Flavonoids } \\
(\% w / w \pm \mathrm{SD})\end{array}$} & \multicolumn{2}{|c|}{$\begin{array}{c}\text { Antioxidant Capacity Assays } \\
\text { (\% of Inhibition) }\end{array}$} \\
\hline & & & & & & DPPH & ABTS \\
\hline \multirow{16}{*}{ Mesocarp } & \multirow{4}{*}{$\begin{array}{l}\text { Cold } \\
\text { maceration }\end{array}$} & 100 & $30.18 \pm 1.45$ & $14.60 \pm 0.42$ & $14.51 \pm 0.24$ & $77.34 \pm 2.13$ & $74.09 \pm 1.48^{* *}$ \\
\hline & & 80 & $28.22 \pm 1.28$ & $9.59 \pm 0.50$ & $10.06 \pm 0.36$ & $58.16 \pm 2.29$ & $44.12 \pm 3.21$ \\
\hline & & 50 & $22.16 \pm 1.52$ & $5.23 \pm 0.30$ & $2.54 \pm 0.19$ & $33.91 \pm 1.78$ & $25.80 \pm 1.47$ \\
\hline & & 20 & $13.49 \pm 0.61$ & $2.64 \pm 0.16$ & $1.12 \pm 0.08$ & $15.14 \pm 0.76$ & $10.06 \pm 0.42$ \\
\hline & \multirow{4}{*}{$\begin{array}{c}\text { Hot } \\
\text { maceration }\end{array}$} & 100 & $36.63 \pm 0.55$ & $15.80 \pm 0.83$ & $15.05 \pm 0.80$ & $74.81 \pm 1.25$ & $73.31 \pm 1.21$ ** \\
\hline & & 80 & $31.95 \pm 2.03$ & $12.34 \pm 0.04$ & $12.50 \pm 0.42$ & $61.10 \pm 1.17$ & $48.91 \pm 3.37$ \\
\hline & & 50 & $27.62 \pm 0.26$ & $6.86 \pm 0.30$ & $3.72 \pm 0.19$ & $33.75 \pm 1.72$ & $24.26 \pm 1.18$ \\
\hline & & 20 & $20.49 \pm 0.85$ & $3.64 \pm 0.14$ & $1.64 \pm 0.10$ & $16.72 \pm 0.78$ & $9.95 \pm 0.31$ \\
\hline & \multirow{4}{*}{$\begin{array}{l}\text { Neutral } \\
\text { sonication }\end{array}$} & 100 & $27.88 \pm 1.36$ & $14.12 \pm 0.72$ & $12.93 \pm 0.42$ & $72.78 \pm 1.16$ & $70.38 \pm 1.55$ \\
\hline & & 80 & $25.62 \pm 0.62$ & $11.50 \pm 0.48$ & $11.26 \pm 0.99$ & $54.30 \pm 1.12$ & $51.05 \pm 2.50$ \\
\hline & & 50 & $24.26 \pm 0.25$ & $6.42 \pm 0.59$ & $4.29 \pm 0.15$ & $34.26 \pm 1.71$ & $24.27 \pm 1.23$ \\
\hline & & 20 & $19.84 \pm 0.73$ & $2.86 \pm 0.23$ & $0.97 \pm 0.04$ & $10.18 \pm 0.94$ & $8.59 \pm 0.66$ \\
\hline & \multirow{4}{*}{$\begin{array}{l}\text { Acid } \\
\text { sonication }\end{array}$} & 100 & $16.98 \pm 0.69$ & $14.31 \pm 0.53$ & $13.95 \pm 0.62$ & $74.14 \pm 1.31$ & $73.49 \pm 2.82 * *$ \\
\hline & & 80 & $18.25 \pm 1.34$ & $10.22 \pm 0.54$ & $10.87 \pm 0.48$ & $54.61 \pm 4.20$ & $39.18 \pm 1.80$ \\
\hline & & 50 & $14.95 \pm 0.61$ & $6.38 \pm 0.46$ & $6.18 \pm 0.41$ & $35.02 \pm 1.42$ & $20.48 \pm 1.10$ \\
\hline & & 20 & $11.70 \pm 0.49$ & $3.58 \pm 0.19$ & $1.06 \pm 0.03$ & $14.96 \pm 1.02$ & $10.19 \pm 0.41$ \\
\hline \multirow{16}{*}{ Epicarp } & \multirow{4}{*}{$\begin{array}{l}\text { Cold } \\
\text { maceration }\end{array}$} & 100 & $10.90 \pm 0.26$ & $6.51 \pm 0.41$ & $2.85 \pm 0.15$ & $52.14 \pm 2.23$ & $54.89 \pm 1.92$ \\
\hline & & 80 & $17.32 \pm 0.56$ & $5.47 \pm 0.25$ & $2.03 \pm 0.11$ & $34.56 \pm 1.78$ & $32.90 \pm 1.08$ \\
\hline & & 50 & $15.79 \pm 0.76$ & $3.56 \pm 0.22$ & $1.04 \pm 0.09$ & $15.47 \pm 1.00$ & $14.69 \pm 0.96$ \\
\hline & & 20 & $8.85 \pm 0.29$ & $3.57 \pm 0.18$ & $0.68 \pm 0.04$ & $5.07 \pm 0.39$ & $9.08 \pm 0.59$ \\
\hline & \multirow{4}{*}{$\begin{array}{l}\text { Hot } \\
\text { maceration }\end{array}$} & 100 & $12.69 \pm 0.53$ & $7.02 \pm 0.31$ & $3.97 \pm 0.23$ & $53.36 \pm 2.37$ & $58.58 \pm 2.62$ \\
\hline & & 80 & $14.47 \pm 0.83$ & $5.15 \pm 0.37$ & $2.37 \pm 0.16$ & $38.84 \pm 1.94$ & $38.87 \pm 0.42$ \\
\hline & & 50 & $13.38 \pm 0.58$ & $4.70 \pm 0.26$ & $1.09 \pm 0.09$ & $25.05 \pm 1.54$ & $17.15 \pm 1.06$ \\
\hline & & 20 & $10.66 \pm 0.59$ & $4.40 \pm 0.27$ & $0.61 \pm 0.04$ & $13.08 \pm 1.03$ & $9.12 \pm 0.44$ \\
\hline & \multirow{4}{*}{$\begin{array}{l}\text { Neutral } \\
\text { sonication }\end{array}$} & 100 & $4.84 \pm 0.23$ & $7.14 \pm 0.39$ & $6.95 \pm 0.30$ & $53.77 \pm 1.75$ & $56.44 \pm 0.36$ \\
\hline & & 80 & $7.80 \pm 0.38$ & $6.24 \pm 0.23$ & $4.92 \pm 0.20$ & $46.00 \pm 2.33$ & $39.99 \pm 1.59$ \\
\hline & & 50 & $10.94 \pm 0.69$ & $5.35 \pm 0.29$ & $2.99 \pm 0.16$ & $30.06 \pm 2.35$ & $18.17 \pm 0.68$ \\
\hline & & 20 & $13.73 \pm 0.74$ & $3.27 \pm 0.15$ & $0.57 \pm 0.04$ & $12.23 \pm 0.71$ & $7.81 \pm 0.54$ \\
\hline & \multirow{4}{*}{$\begin{array}{l}\text { Acid } \\
\text { sonication }\end{array}$} & 100 & $6.40 \pm 0.39$ & $7.22 \pm 0.16$ & $6.51 \pm 0.39$ & $55.91 \pm 0.86$ & $60.23 \pm 2.52$ \\
\hline & & 80 & $7.97 \pm 0.07$ & $6.62 \pm 0.31$ & $3.58 \pm 0.25$ & $42.63 \pm 2.89$ & $41.75 \pm 2.48$ \\
\hline & & 50 & $10.72 \pm 0.32$ & $6.58 \pm 0.32$ & $2.92 \pm 0.25$ & $30.52 \pm 0.75$ & $22.08 \pm 1.23$ \\
\hline & & 20 & $13.19 \pm 0.87$ & $4.02 \pm 0.08$ & $0.59 \pm 0.03$ & $14.65 \pm 0.93$ & $11.00 \pm 0.84$ \\
\hline
\end{tabular}




\subsection{Crude Extraction Yield}

The crude extraction yield (CEY) was significantly influenced by the solvent-water ratio. Mesocarp samples (MS) presented a higher CEY (36.63\%) than any epicarp samples, highlighting the different chemical compositions of each fruit part. For MS, most of the tested methods presented an increasing pattern of CEY until 100\% ethanol was used as the extraction solvent. An exception was observed for acid sonication, in which the highest CEY was obtained with $80 \%$ ethanol (Table 1). Methods applied to epicarp samples (ES) were distinctively influenced by the percentage of ethanol in the extraction solvent. Maceration methods presented an increasing CEY until 80\% ethanol, while ultrasonicbased methods decreased CEY linearly as more ethanol was used in the extraction solvent (Table 1). The different behaviour observed in sonication methods may be associated with the increase in the extraction solvent viscosity caused by the addition of ethanol, which reduces the cavitation process within the solvent [31]. Of the tested methods, the maceration techniques showed the highest extraction yields for both sample types. The CEY of maceration methods was also significantly influenced by the extraction temperature of the extraction method. When $80 \%$ ethanol (which was the solvent that produced the highest CEY of ES) was used, the highest temperature increased CEY by approximately $20 \%$ for both sample types (Table 1 ).

\subsection{Chemical Characterization}

The ethanolic extracts of epicarp and mesocarp were partitioned with medium polarity solvents (dichloromethane and ethyl acetate) and fractionated using chromatographic techniques to isolate the major compounds of these residues. Different open-column chromatography fractionations with silica gel and low-to-medium polarity solvents were performed, which returned the isolation of two substances, with one returned from each bacuri fruit part. The substances were evaluated by mass spectrometry and nuclear magnetic resonance, showing similar structures and the same low resolution molecular mass: prenylated benzophenones with mass 602 u.m.a. In samples from the epicarp, the tautomers from garcinielliptone (Figure 1) were detected using APCI mass spectrometry with $m / z 603$ (positive mode) and $m / z 601$ (negative mode). This is a common substance in the Clusiaceae family and Garcinia genus. The confirmation was performed by NMR experiments with ${ }^{1} \mathrm{H},{ }^{13} \mathrm{C}, \mathrm{HSQC}$ and $\mathrm{HMBC}$, the results of which were compared with literature data obtained in $\mathrm{CDCl}_{3}[32,33]$, together with the analysis of the fragments $m / z 465$ and $m / z 409$ observed by MSn from $m / z 601$ ionized in APCI (-) [34].

From the mesocarp, another prenylated benzophenone, 30-epi-cambogin, was isolated. With the same molecular mass, 602 u.m.a., MS ${ }^{n}$ from $m / z 601$ ionized in APCI (-) allowed the observation of fragments such as $m / z 136$, which is typical from phloroglucinol units. The confirmation was also performed by ${ }^{1} \mathrm{H},{ }^{13} \mathrm{C}, \mathrm{HSQC}$ and HMBC NMR experiments, the results of which were compared with literature data (obtained in $\mathrm{CD}_{3} \mathrm{OD}$ ) [35].

\subsection{Evaluation of Phenolic Composition and Antioxidant Capacity}

Phenolic and flavonoid compounds are known antioxidants agents that are capable of inhibiting the oxidation of low-density lipoproteins and stabilizing unstable radicals. Therefore, their content can be used to assess the nutritional value and biological properties of different matrices $[1,4,5]$. To evaluate the effects of the extraction methods and solvent compositions on the total flavonoid content, total phenolic content and antioxidant capacity, it was first evaluated whether these response variables have high linear correlation (nominal correlation higher than 0.800 ) using multivariate analysis (MANOVA). High correlation can provide insight if response variables are independent from each other and also highlight which statistical methods is better suited for analysing the data. Correlation between each response variable was weak within both sample types during MANOVA (Table 2), indicating the need for individual analysis instead of multivariate. Thus, an individual factorial experimental design was adopted for each of these response variables. 

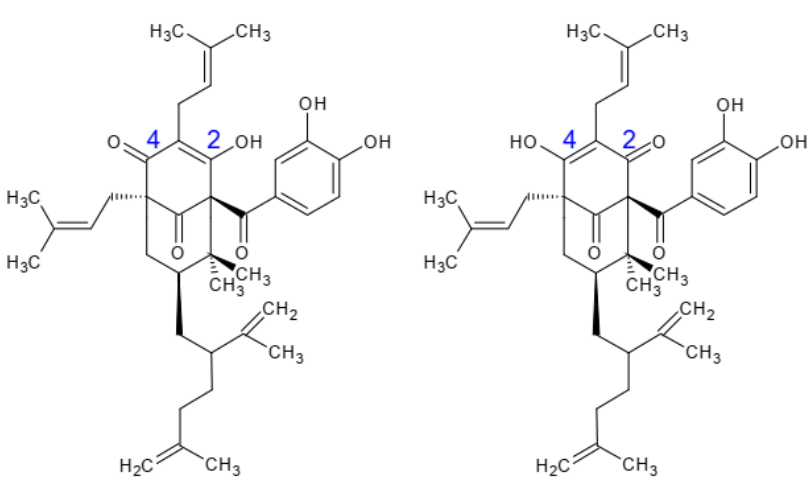

Garcinielliptone FC tautomers (carbons 2 and 4)

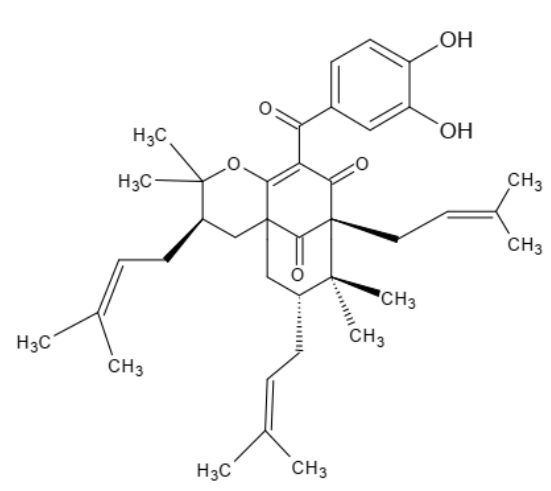

30-epi-cambogin

Figure 1. Identified prenylated benzophenones on epicarp (garcinielliptone FC tautomers) and mesocarp (30-epi-cambogin).

Table 2. Multivariate analysis correlation matrix of the response variables screened.

\begin{tabular}{cccccccccccc}
\hline \multicolumn{1}{c}{ Mesocarp Samples } \\
$\begin{array}{c}\text { Response- } \\
\text { variables }\end{array}$ & TFC & TPC & CEY & DPPH & ABTS & TFC & TPC & CEY & DPPH & ABTS \\
\hline TFC & 1.0000 & -0.0104 & 0.1124 & 0.2391 & -0.0035 & 1.0000 & -0.0021 & 0.1067 & 0.1312 & 0.2697 \\
\hline TPC & -0.0104 & 1.0000 & -0.3430 & -0.0510 & 0.0334 & -0.0021 & 1.0000 & 0.1552 & -0.1947 & 0.3763 \\
\hline CEY & 0.1124 & -0.3430 & 1.0000 & -0.0862 & 0.0992 & 0.1067 & 0.1552 & 1.0000 & 0.0352 & 0.1225 \\
\hline DPPH & 0.2391 & -0.0510 & -0.0862 & 1.0000 & -0.0684 & 0.1312 & -0.1947 & 0.0352 & 1.0000 & 0.0299 \\
\hline ABTS & -0.0035 & 0.0334 & 0.0992 & -0.0684 & 1.0000 & 0.2697 & 0.3763 & 0.1225 & 0.0299 & 1.0000 \\
\hline
\end{tabular}

TPC = Total phenolic content; TFC = Total flavonoid content; $\mathrm{CEY}=$ Crude extraction yield; DPPH = Antioxidant capacity by DDPH assay; ABTS $=$ Antioxidant capacity by DDPH assay.

Since the correlation of response variables by multivariate statistic was weak (Table 2), univariate analysis of variance (ANOVA) was conducted. ANOVA demonstrated that within each response variable there was a significant interaction effect between the extraction method and solvent composition, with $p$-value $<0.0001$, indicating the possibility to screening method performance through response surface methods.

Response surface methodology demonstrated that the extraction method, temperature and $\mathrm{pH}$ did not significantly affect the results of mesocarp extraction, producing planelike surfaces (Figure 2). Total phenolic content, total flavonoid content, and antioxidant activities of DPPH and ABTS assays exhibited qualitatively the same pattern observed for the crude extraction yield, with almost all linearly increasing as ethanol proportion in the solvent increased from 20 to $100 \%$. These increases were 4.7 -fold (Figure 2a), 13-fold (Figure 2b), 5-fold (Figure 2c) and 7-fold (Figure 2d), respectively, which suggests that these classes of compounds are linked to the matrix through different types of bonds. Such increases can be related, in general, to the ability of ethanol to induce disruption of vegetable cell membranes, thereby enhancing solvent permeability into the solid matrix [36]. The more effective the extraction of phenolic compounds and flavonoids, the stronger the antioxidant activity almost regardless of their detection method.

In epicarp samples, the type of extraction method had a significant impact on the total content of both phenolic compounds (Figure 3a) and flavonoids (Figure 3b). Ultrasound methods produced higher yields of bioactive compounds compared to maceration methods. The ultrasound-assisted methods had as a major extraction mechanism, the sonication phenomenon, which produced soundwave shocks capable of disrupting plant cells, and thus facilitated the diffusion of the solvent into the plant matrix [31]. Even though the effects of the considered factors on the radical scavenging activity of epicarp samples were 
in general not statistically significant (Table 1), it was possible to observe an increase in the ABTS radical inhibition when ultrasound methods were applied (Figure 3d).

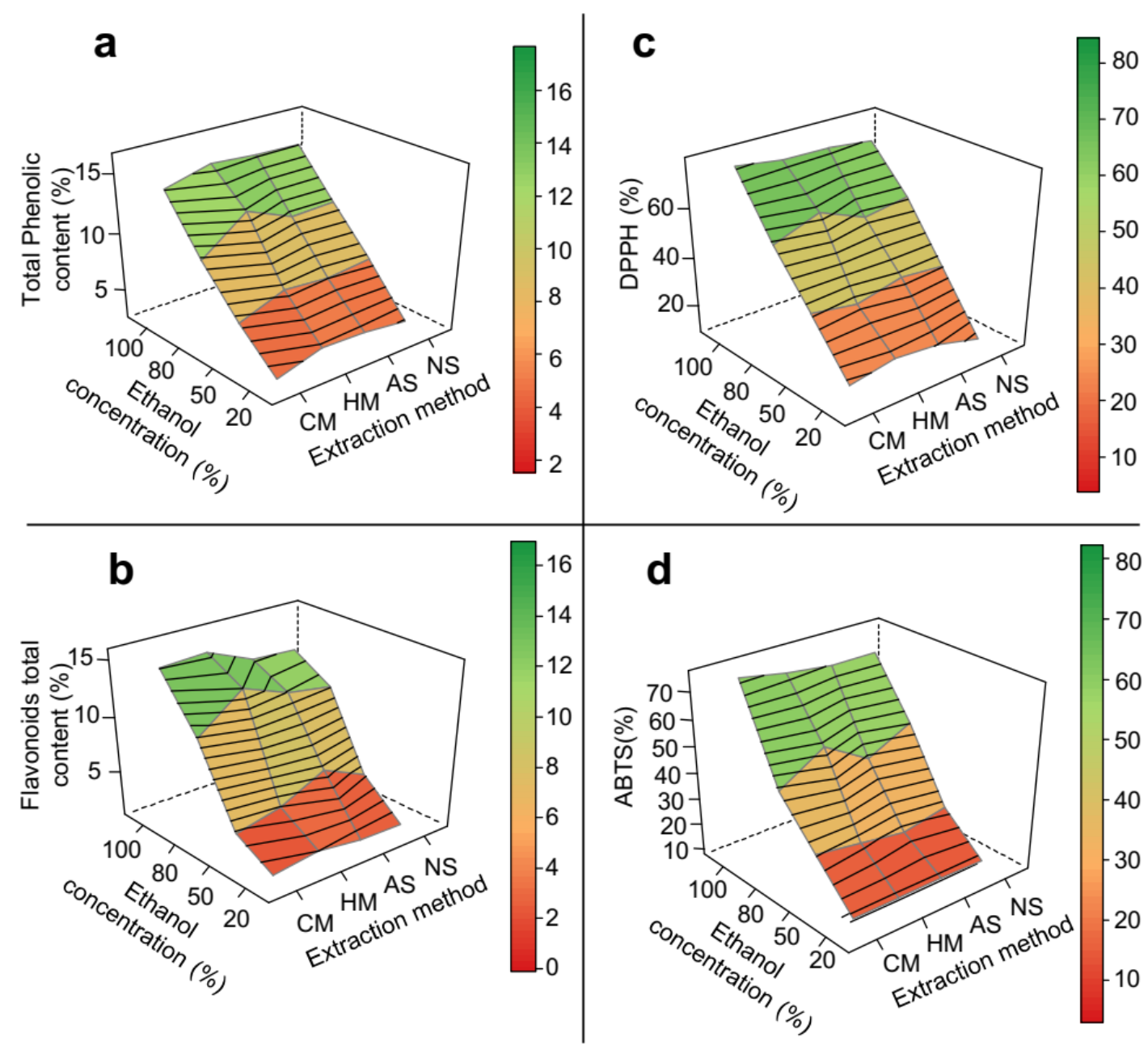

Figure 2. 3D response surface graph of the optimization of phenolic extraction from P. insignis mesocarp. (a) Total phenolic, (b) Total flavonoid, (c) DPPH, and (d) ABTS. CM = cold maceration; HM = hot maceration; AS = acid sonication; NS = neutral sonication; DPPH = Antioxidant capacity by DDPH assay; ABTS = Antioxidant capacity by DDPH assay.

The different results obtained with AS and NS indicate that a change in the $\mathrm{pH}$ of the extraction solution interfered with ES extraction performance (Figure 3). In contrast to the extraction yield, there was a significant increase (approximately 13\%) in the effectiveness of phenolic compound and flavonoid extraction when a more acidic medium was used for AS, but not for NS (Table 1, Figure 3). Similar results have been reported in the optimization of phenolics extraction from other plant matrices such as Citrus reticulata [37]. In general, the acidity increased the flavonoid content by inducing the cleavage of their bond with proteins and favoring their occurrence in medium as protonated molecules [23,37].

As expected, for both PS and ES, a rise in the extraction temperature improved the results of all the response variable (Figures 2 and 3). An increase in temperature is known to favour the extraction of some classes of phenolic compounds by (a) increasing their solubility and diffusion rate, (b) reducing the solvent surface tension and viscosity and (c) increasing ethanol reactivity due to a decrease in its dielectric constant $[21,23,31,37]$. However, the use of high temperatures in phenolic extraction must be closely monitored, given that temperatures that are too high temperatures can expose the bioactive compounds to the risk of degradation [24]. Previous optimization studies on the extraction of phenolics and antioxidant compounds from Theobroma cocoa shells, Olea europaeae, green tea, and 
Citrus species have shown the highest recovery rates at temperatures ranging from $43{ }^{\circ} \mathrm{C}$ to $70{ }^{\circ} \mathrm{C}[18,20,38-40]$.

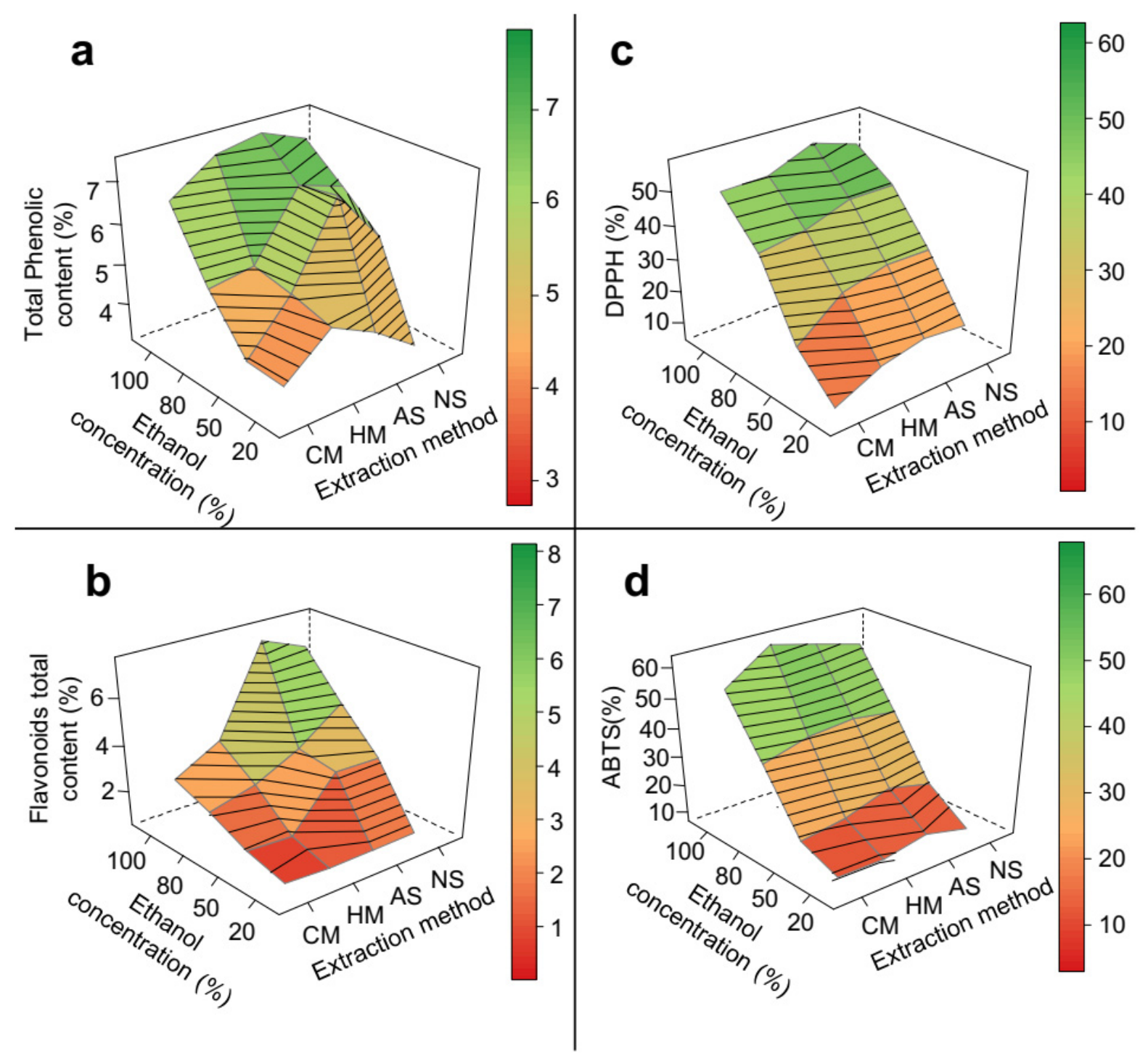

Figure 3. 3D response surface graph of the optimization of phenolic extraction from P. insignis epicarp. (a) Total phenolic, (b) Total flavonoid, (c) DPPH, and (d) ABTS. CM = cold maceration; HM = hot maceration; AS = acid sonication; NS = neutral sonication; DPPH = Antioxidant capacity by DDPH assay; ABTS = Antioxidant capacity by DDPH assay.

It is worth mentioning that using all extraction methods, an increased ethanol fraction in the solvent improved the results of all response variables for both PS and ES extraction. There are several features of the extraction solvent that can influence its efficacy. Due to differences in polarity, intermolecular interactions and stereochemistry, there is no suitable solvent extraction system to recover specific classes of natural antioxidants, and the efficacy of a specific solvent will depend on the matrix and its chemical profile. For instance, more nonpolar flavonoids will require less polar extraction solvents [23,37,41].

It is believed that the type of solvent, temperature and $\mathrm{pH}$ can determine the quantity of phenolic compounds to be extracted [23]. However, it is not possible to find data in the literature that relate these three parameters with the aim of identifying an ideal standard condition. Since each raw material has its own characteristics that depend on the matrix chemical composition, the identification of the optimal extraction parameters is of paramount important for successful recovery of bioactive compounds. 


\section{Conclusions}

Statistical methods such as the response surface methodology are widely used as tools to optimize processes for the recovery of various chemical components from different fruits. Although some variables investigated in this study, such as the antioxidant activity in absolute ethanol, did not show statistical differences in their results, this tool allowed for the analysis of the whole dataset successfully. From the results of extraction yield, content of total phenolic compounds and total flavonoids, and antioxidant activity by both DPPH and ABTS assays, we identified hot maceration with $100 \%$ ethanol and sonication aided by hydrochloric acid added to $100 \%$ ethanol as the optimal extraction method for bacuri mesocarp and epicarp, respectively.

Author Contributions: Conceptualization, K.K.L.Y., E.S.L. and V.F.V.-J.; methodology, K.K.L.Y., E.S.L. and V.F.V.-J.; formal analysis, K.K.L.Y., A.S.A., M.S.L., K.F.A.C., E.S.L. and V.F.V.-J.; investigation, K.K.L.Y., K.F.A.C., C.V.L., D.S.D., E.S.L. and V.F.V.-J.; resources, K.K.L.Y., C.V.L., E.S.L. and V.F.V.-J.; writing - original draft preparation, K.K.L.Y., C.V.L., A.C., E.S.L. and V.F.V.-J.; writing—review and editing, K.K.L.Y., A.C., E.S.L. and V.F.V.-J.; supervision, E.S.L. and V.F.V.-J.; project administration, K.K.L.Y., E.S.L. and V.F.V.-J.; funding acquisition, E.S.L. and V.F.V.-J. All authors have read and agreed to the published version of the manuscript.

Funding: This research received scholarship funding from CNPq, FAPEAM, FAPERJ and CAPES.

Institutional Review Board Statement: Not applicable.

Informed Consent Statement: Not applicable.

Conflicts of Interest: The authors declare no conflict of interest. The funders had no role in the design of the study; in the collection, analyses, or interpretation of data; in the writing of the manuscript, or in the decision to publish the results.

\section{References}

1. Lustosa, A.K.M.F.; Arcanjo, D.D.R.; Ribeiro, R.G.; Rodrigues, K.A.F.; Passos, F.F.B.; Piauilino, C.A.; Silva-Filho, J.C.; Araújo, B.Q.; Lima-Neto, J.S.; Costa-Júnior, J.S.; et al. Immunomodulatory and toxicological evaluation of the fruit seeds from Platonia insignis, a native species from Brazilian Amazon rainforest. Rev. Bras. Farmacogn. 2016, 26, 77-82. [CrossRef]

2. Teixeira, N.; Melo, J.C.S.; Batista, L.F.; Paula-Souza, J.; Fronza, P.; Brandão, M.G.L. Edible fruits from Brazilian biodiversity: A review on their sensorial characteristics versus bioactivity as tool to select research. Food Res. Int. 2019, 119, 325-348. [CrossRef] [PubMed]

3. Clerici, M.T.P.S.; Carvalho-Silva, L.B. Nutritional bioactive compounds and technological aspects of minor fruits grown in Brazil. Food Res. Int. 2011, 44, 1658-1670. [CrossRef]

4. de Carvalho, J.E.U.; do Nascimento, W.M.O. Technological innovations in the propagation of Açaí palm and Bacuri. Rev. Bras. Frutic. 2018, 40. [CrossRef]

5. Botelho, M.G.L.; Homma, A.K.O.; Furtado, L.G.; LIma, M.d.C.S.; Costa, M.d.S.S. Productive and market potential of bacuri fruit (Platonia insignis Mart.) in Pará, Brazil. Res. Soc. Dev. 2020, 9, 1-6. [CrossRef]

6. Fontenele, M.A.; de Figueiredo, R.W.; Maia, G.A.; Alves, R.E.; de Sousa, P.H.M.; de Souza, V.A.B. Conservação pós-colheita de bacuri (Platonia insignis Mart.) sob refrigeração e embalado em PVC. Rev. Ceres 2010, 57, 292-296. [CrossRef]

7. Bezerra, G.D.; Maia, G.A.; de Figueiredo, R.W.; de Souza, M.D. Potencial agroeconômico do bacuri: Revisão. Bol. Cent. Pesqui. Process. Aliment. 2005, 23, 47-58. [CrossRef]

8. Rufino, M.d.S.M.; Alves, R.E.; de Brito, E.S.; Pérez-Jiménez, J.; Saura-Calixto, F.; Mancini-Filho, J. Bioactive compounds and antioxidant capacities of 18 non-traditional tropical fruits from Brazil. Food Chem. 2010, 121, 996-1002. [CrossRef]

9. Uekane, T.M.; Nicolotti, L.; Griglione, A.; Bizzo, H.R.; Rubiolo, P.; Bicchi, C.; Rocha-Leão, M.H.M.; Rezende, C.M. Studies on the volatile fraction composition of three native Amazonian-Brazilian fruits: Murici (Byrsonima crassifolia L., Malpighiaceae), bacuri (Platonia insignis M., Clusiaceae), and sapodilla (Manilkara sapota L., Sapotaceae). Food Chem. 2017, 219, 13-22. [CrossRef]

10. do Nascimento Cavalcante, A.; Lima, L.K.F.; Araújo, C.M.; da Silva Santos, F.P.; do Nascimento, M.O.; de Castro e Sousa, J.M.; Rai, M.; Feitosa, C.M. Toxicity, cytotoxicity, mutagenicity and in vitro antioxidant models of 2-oleyl-1,3-dipalmitoyl-glycerol isolated from the hexane extract of Platonia insignis MART seeds. Toxicol. Rep. 2020, 7, 209-216. [CrossRef] [PubMed]

11. Faria, J.V.; Valido, I.H.; Paz, W.H.P.; da Silva, F.M.A.; de Souza, A.D.L.; Acho, L.R.D.; Lima, E.S.; Boleti, A.P.A.; Marinho, J.V.N.; Salvador, M.J.; et al. Comparative evaluation of chemical composition and biological activities of tropical fruits consumed in Manaus, central Amazonia, Brazil. Food Res. Int. 2021, 139, 109836. [CrossRef]

12. Chendynski, L.T.; Cordeiro, T.; Messias, G.B.; Mantovani, A.C.G.; Spacino, K.R.; Zeraik, M.L.; Borsato, D. Evaluation and application of extracts of rosemary leaves, araçá pulp and peel of bacuri in the inhibition of the oxidation reaction of biodiesel. Fuel 2020, 261, 116379. [CrossRef] 
13. Da Silva, A.P.D.S.C.L.; Oliveira, G.L.D.S.; Medeiros, S.C.; Sousa, A.M.L.; Lopes, L.D.S.; David, J.M.; Junior, J.S.D.C.; De Freitas, R.M. Pre-clinical toxicology of garcinielliptone FC, a tautomeric pair of polyprenylated benzophenone, isolated from Platonia insignis Mart seeds. Phytomedicine 2016, 23, 477-482. [CrossRef]

14. Barbosa, P.C.S.; Wiedemann, L.S.M.; Medeiros, R.S.; Da Veiga Junior, V.F. Phytochemical Fingerprints of Copaiba Oils (Copaifera multijuga HAYNE) Determined by Multivariate Analysis. Chem. Biodivers. 2013, 10, 1350-1360. [CrossRef] [PubMed]

15. Nakamura, C.V.; Dos Santos, A.O.; Ueda-Nakamura, T.; Dias Filho, B.P.; Da Veiga Junior, V.F. Copaiba oil: An alternative to development of new drugs against leishmaniasis. Evid.-Based Complement. Altern. Med. 2012, 2012. [CrossRef]

16. Morais, B.D.M.; Silva Júnior, M.E.; Andrade, S.A.C.; Converti, A.; Silva, M.F.; Maciel, M.I.S. Optimization of Red Mombin Juice Spray Drying: Physicochemical and Sensory Analyses of Powders. Chem. Eng. Technol. 2020, 43, 1832-1840. [CrossRef]

17. Koohi, S.; Nasernejad, B.; Zare, M.H.; Elahifard, M.; Shirazian, S.; Ghadiri, M. Extraction of Oxidative Enzymes from Green Tea Leaves and Optimization of Extraction Conditions. Chem. Eng. Technol. 2020, 43, 2548-2556. [CrossRef]

18. Md Yusof, A.H.; Abd Gani, S.S.; Zaidan, U.H.; Halmi, M.I.E.; Zainudin, B.H. Optimization of an Ultrasound-Assisted Extraction Condition for Flavonoid Compounds from Cocoa Shells (Theobroma cacao) Using Response Surface Methodology. Molecules 2019, 24, 711. [CrossRef]

19. Antonio, A.D.S.; Aguiar, A.T.C.; Santos, G.R.C.D.; Pereira, H.M.G.; Veiga-Junior, V.F.D.; Wiedemann, L.S.M. Phytochemistry by design: A case study of the chemical composition of: Ocotea guianensis optimized extracts focused on untargeted metabolomics analysis. RSC Adv. 2020, 10, 3459-3471. [CrossRef]

20. Assefa, A.D.; Saini, R.K.; Keum, Y.S. Extraction of antioxidants and flavonoids from yuzu (Citrus junos Sieb ex Tanaka) peels: A response surface methodology study. J. Food Meas. Charact. 2017, 11, 364-379. [CrossRef]

21. Hilali, S.; Fabiano-Tixier, A.S.; Ruiz, K.; Hejjaj, A.; Ait Nouh, F.; Idlimam, A.; Bily, A.; Mandi, L.; Chemat, F. Green Extraction of Essential Oils, Polyphenols, and Pectins from Orange Peel Employing Solar Energy: Toward a Zero-Waste Biorefinery. ACS Sustain. Chem. Eng. 2019, 7, 11815-11822. [CrossRef]

22. Ciğeroğlu, Z.; Bayramoğlu, M.; Kırbaşlar, Ş.İ; Şahin, S. Comparison of microwave-assisted techniques for the extraction of antioxidants from Citrus paradisi Macf. biowastes. J. Food Sci. Technol. 2020, 58, 1190-1198. [CrossRef]

23. Alara, O.R.; Abdurahman, N.H.; Ukaegbu, C.I. Extraction of phenolic compounds: A review. Curr. Res. Food Sci. 2021, 4, 200-214. [CrossRef]

24. Vagiri, M.; Ekholm, A.; Andersson, S.C.; Johansson, E.; Rumpunen, K. An optimized method for analysis of phenolic compounds in buds, leaves, and fruits of black currant (ribes nigrum 1.). J. Agric. Food Chem. 2012, 60, 10501-10510. [CrossRef] [PubMed]

25. Petreska Stanoeva, J.; Balshikevska, E.; Stefova, M.; Tusevski, O.; Simic, S.G. Comparison of the Effect of Acids in Solvent Mixtures for Extraction of Phenolic Compounds From Aronia melanocarpa. Nat. Prod. Commun. 2020, 15. [CrossRef]

26. Johnson, R.A.; Wichern, D.W. Applied Multivariate Statistical Analysis, 6th ed.; Pearson Prentice Hall: Hoboken, NJ, USA, 2007.

27. Singleton, V.L.; Rossi, J.A.J. Colorimetry of total phenolics with phosphomolybdic-phosphotungstic acid reagents. Am. J. Enol. Vitic. 1965, 16, 144-158.

28. Chang, C.C.; Yang, M.H.; Wen, H.M.; Chern, J.C. Estimation of total flavonoid content in propolis by two complementary colorimetric methods. J. Food Drug Anal. 2002, 10, 178-182.

29. Re, R.; Pellegrini, N.; Proteggent, A.; Pannala, A.; Yang, M.; Rice-Evans, C. Antioxidant activity applying an improved ABTS+ radical cation decolorization assay. Free Radic. Biol. Med. 1998, 26, 1231-1237. [CrossRef]

30. Molyneux, P. The use of the stable free radical diphenylpicrylhydrazyl (DPPH) for estimating antioxidant activity. J. Sci. Tech. 2004, 26, 211-219.

31. Chemat, F.; Rombaut, N.; Sicaire, A.G.; Meullemiestre, A.; Fabiano-Tixier, A.S.; Abert-Vian, M. Ultrasound assisted extraction of food and natural products. Mechanisms, techniques, combinations, protocols and applications. A review. Ultrason. Sonochem. 2017, 34, 540-560. [CrossRef]

32. Silva, A.P.; Silva, M.P.; Oliveira, C.G.; Monteiro, D.C.; Pinto, P.L.; Mendonça, R.Z.; Costa Júnior, J.S.; Freitas, R.M.; de Moraes, J. Garcinielliptone FC: Antiparasitic activity without cytotoxicity to mammalian cells. Toxicol. Vitr. 2015, 29, 681-687. [CrossRef]

33. Costa Junior, J.S.; de Almeida, A.A.; Ferraz, A.D.; Rossatto, R.R.; Silva, T.G.; Silva, P.B.; Militão, G.C.; Citó, A.M.; Santana, L.C.; Carvalho, F.A.; et al. Cytotoxic and leishmanicidal properties of garcinielliptone FC, a prenylated benzophenone from Platonia insignis. Nat. Prod. Res. 2013, 27, 470-474. [CrossRef]

34. Piccinelli, A.L.; Campone, L.; Dal Piaz, F.; Cuesta-Rubio, O.; Rastrelli, L. Fragmentation Pathways of Polycyclic Polyisoprenylated Benzophenones and Degradation Profile of Nemorosone by Multiple-Stage Tandem Mass Spectrometry. J. Am. Soc. Mass Spectrom. 2009, 20, 1688-1698. [CrossRef]

35. Fuller, R.W.; Blunt, J.W.; Boswell, J.L.; Cardellina, J.H.; Boyd, M.R. Guttiferone F, the first prenylated benzophenone from Allanblackia stuhlmannii. J. Nat. Prod. 1999, 62, 130-132. [CrossRef] [PubMed]

36. Chemat, F.; Abert-Vian, M.; Fabiano-Tixier, A.S.; Strube, J.; Uhlenbrock, L.; Gunjevic, V.; Cravotto, G. Green extraction of natural products. Origins, current status, and future challenges. TrAC-Trends Anal. Chem. 2019, 118, 248-263. [CrossRef]

37. Chaves, J.O.; de Souza, M.C.; da Silva, L.C.; Lachos-Perez, D.; Torres-Mayanga, P.C.; Machado, A.P.d.F.; Forster-Carneiro, T.; Vázquez-Espinosa, M.; González-de-Peredo, A.V.; Barbero, G.F.; et al. Extraction of Flavonoids From Natural Sources Using Modern Techniques. Front. Chem. 2020, 8, 507887. [CrossRef] [PubMed] 
38. Bae, I.K.; Ham, H.M.; Jeong, M.H.; Kim, D.H.; Kim, H.J. Simultaneous determination of 15 phenolic compounds and caffeine in teas and mate using RP-HPLC/UV detection: Method development and optimization of extraction process. Food Chem. 2015, 172, 469-475. [CrossRef] [PubMed]

39. Irakli, M.; Chatzopoulou, P.; Ekateriniadou, L. Optimization of ultrasound-assisted extraction of phenolic compounds: Oleuropein phenolic acids, phenolic alcohols and flavonoids from olive leaves and evaluation of its antioxidant activities. Ind. Crops Prod. 2018, 124, 382-388. [CrossRef]

40. Li, H.-Z.; Zhang, Z.-J.; Xue, J.; Cui, L.-X.; Hou, T.; Li, X.-J.; Chen, T. Optimization of ultrasound-assisted extraction of phenolic compounds, antioxidants and rosmarinic acid from perilla leaves using response surface methodology. Food Sci. Technol. 2016, 36, 686-693. [CrossRef]

41. Xu, D.P.; Zheng, J.; Zhou, Y.; Li, Y.; Li, S.; Li, H. Bin Ultrasound-assisted extraction of natural antioxidants from the flower of Limonium sinuatum: Optimization and comparison with conventional methods. Food Chem. 2017, 217, 552-559. [CrossRef] 